\title{
Student Learning Motivation: Word Square Learning Model
}

\author{
Aji Heru Muslim ${ }^{1 *}$, Anik Ghufron ${ }^{2}$, Wuri Wuryandani ${ }^{3}$ \\ \{ ajiheru.2020@student.uny.ac.id ${ }^{1}$, ajiherumuslim@ump.ac.id ${ }^{1}$ \} \\ ${ }^{1}$ Elementary School Teacher Education, Universitas Muhammadiyah Purwokerto, \\ Jl. KH. Ahmad Dahlan, Purwokerto 53182 \\ ${ }^{1,2,3}$ Department of Basic Education Study Program, Yogyakarta State University, \\ Jl. Colombo No 1, Yogyakarta 55281
}

\begin{abstract}
The type of research used is literature review research, where data collection is done by searching for journals on the GARUDA search site. The research procedure includes Organize, Synthesize, and Identify. The data collected in the study were obtained from literature on literature related to the use of the word square learning model. Based on the results of research on the literature about the research topic, it can be concluded that the use of the word square learning model can stimulate the emergence of learning motivation in students; the square learning model is by the characteristics of elementary students, improves students' listening skills, and the teacher's role as facilitator and motivator in learning activities.
\end{abstract}

Keywords: word square learning model, student learning motivation

\section{Introduction}

Learning is one aspect that is very meaningful and necessary in life. Learning in Law no. 20 of 2003 concerning the national education system is defined as student interaction with educators and learning resources in a learning environment. Based on this understanding, there are three essential aspects of the learning process: students, educators, and learning resources. If one of the three aspects is lacking, then the learning process will not occur; therefore, learning is considered essential in schools' education.

The learning process delivered by teachers in schools is expected to make students gain new knowledge. The method of receiving new knowledge or receiving information from students is not as easy as imagined. Several factors determine that learning can be said to be successful. These factors include factors originating from within students (internal factors) and factors arising from outside students (external factors) [1].

Student success factors that arise from within and outside affect the teaching and learning process, one of which is motivation. Motivation can be interpreted as the driving force or driving force of a person to be active [2]. Motivation contains a desire that activates, moves, channels, directs attitudes and individual learning behavior.

Motivation is one of the essential elements that students must have; in Slavin's opinion, the reason is one of the most critical components because, with explanation, students are willing to try, actively try, guide, and maintain behavior from time to time [3]. Based on this statement, it can be concluded that student motivation in the learning process is needed to achieve something by what is expected. 
For the objectives in the learning process to be achieved, a teacher must be able to manage the class well. Classroom management is a series of teacher behaviors to create and maintain classroom conditions that enable students to achieve learning goals efficiently and perform quality teaching and learning activities [3,4]. From the above opinion, class management is defined as all efforts directed at creating a practical and fun learning atmosphere and motivating students to run well. Seeing the expert opinion, it can be concluded that the teacher has an essential and significant role in designing and creating good quality learning.

In the learning process, the teacher is recommended to expand and show high enthusiasm to students by presenting learning materials that are better than before. One of the supports for good learning quality is the use of appropriate learning models according to the subject matter of teaching materials, thus meaning that the position of the teacher in learning is a central figure [5]. This requires teachers to produce creative knowledge that can make learning more exciting and can generate student learning motivation so that student involvement in the learning process must be managed as effectively as possible so that students can take part in learning with enthusiasm, do not feel bored, and enthusiastic in receiving subject matter.

One of the learning models that can motivate students to learn is the word square learning model. The word square learning model is a development of the lecture method, which is enriched and oriented to student activity in learning. In its use, this model combines the ability to answer questions with foresight in matching answers to the answer boxes [6]. This model is also used through games; by learning while playing, changes in children's behavior and attitudes will be stimulated by the model used.

The word square learning model is helpful as a motivator and reinforcement for students to the material presented. The word square learning model is effectively used to increase students' learning motivation because the method used in applying this model is fun and entertaining. Learning becomes more exciting and allows active participation from students [5]. The advantages of spreading the word square learning model include creating a pleasant learning atmosphere, increasing student learning activities in shading letters according to answers, being able to train students' careful and critical attitudes, and stimulating students to think effectively [7].

Seeing the advantages of using the word square learning model, researchers feel that this learning model can be an alternative for teachers in presenting appropriate learning materials according to the subject matter of teaching materials because when learning takes place, it can create a pleasant atmosphere that can increase students' learning motivation.

\section{Methodology}

The research method used is literature study research. Literature study research is a series of activities related to collecting library data, reading, taking notes, and processing research materials [8]. In connection with this, this research is in the form of an analysis of the literature by raising the big theme of using the word square learning model, which is discussed based on related articles and learning motivation theory. The data collected in the study were obtained from literature on literature related to the use of the word square learning model. The literature study research procedures are used to organize, synthesize, and identify [9].

\section{Result and Discussion}

Researchers conducted a more in-depth search for Garba Reference Digital (GARUDA) articles and found 76 articles that matched the keyword word square. Of the 76 journal articles found, they were reviewed and re-analyzed. The analysis of this research was carried out continuously in searching for and seeing the results of literature studies by the specified 
keywords; it turned out that there were 22 related journal articles. The articles obtained were processed to seek further information related to the application of learning using word squares. The findings obtained from this literature review are as follows.

a. The word square learning model increases students' learning motivation

In carrying out the learning process using the word square model, many variables can affect learning outcomes: student learning motivation [10]. The literature review found that the word square learning model can increase students' learning motivation in teaching and learning activities $[11,12,13,14,15,16,17]$. Learning is a process of teaching and learning activities carried out to achieve learning objectives. Based on this theory, it can be assumed that students who are motivated to learn will be enthusiastic. In contrast, students who are not motivated will feel the opposite, namely, lazy to learn.

Motivation in learning is defined as the driving force of students to carry out a series of learning activities to achieve the goals. The critical role of motivation in education, namely, determine things that can be used as learning reinforcement, clarify learning goals to be completed, and determine learning perseverance [17]. Based on this explanation, it can be concluded that learning outcomes will be optimal if there is motivation.

A student motivated to learn is essentially influenced by internal (push that comes from within the student) and external (push that comes from outside the student). Factors that influence learning motivation, namely: intelligence, learning needs, interests, personal characteristics, and teaching methods or models [18]. All these factors support each other and are fostered in students so that in the process, a high learning spirit will be created.

As one of the factors that influence learning motivation, the learning model becomes a means for teachers to deliver learning to students. The learning model refers to the learning approach used, including those relating to teaching objectives, stages in learning activities, learning environment, and classroom management, so that through the use of the applied learning model it can provide benefits in the form of presenting innovative learning, which can facilitate students in understanding the subject matter because in its use it is assisted by methods or approaches that are by the level of students' abilities [19].

b. The application of the word square learning model is relevant to the age of elementary school children

The word square learning model is one of the appropriate and relevant learning models for elementary school-age students (SD). The word square learning model can be used for all subjects and is easy for teachers to apply [20, 21, 22, 23, 24]. This model is a teaching and learning activity where the teacher distributes activity sheets or worksheets to measure the level of students' understanding of the subject matter that has been taught. The main instrument of this model is an activity sheet or worksheet in the form of questions or sentences that need to be answered in a random arrangement of letters in the boxes provided.

The word square learning model is a learning model that is similar to filling out crossword puzzles. Still, the primary difference is that this model already has an answer disguised by adding additional boxes as a distraction [25]. The word square learning model is similar in shape to fill in a crossword puzzle; in its use, students need to combine the ability to answer questions with accuracy in matching the answers in the word boxes then students fill them in by shading the letters that have been prepared so that through the use of the model in such learning the teacher can program several selected questions that can stimulate students to think effectively $[7,26]$. 
c. The application of the word square learning model improves students' listening skills

Several literature studies found that the use of the word square learning model can improve students' listening skills. What Agiari, Sudarma, and Suarjana did in their research was to explain the problems faced by students during the learning process, such as students only listening to the material presented by the teacher without understanding the contents of the teacher's explanation. Based on this, students do not understand the material that the teacher has delivered. Agiari, Sudarma, and Suarjana explained that several things caused students not to be able to listen to lessons well, namely, firstly, students were less interested in the material discussed; secondly, students' lack of attention when listening to the material, and thirdly, teachers were less varied when delivering material [27]. Furthermore, the research carried out a learning process using the word square learning model to overcome these learning problems. The word square learning model is a learning model that combines the ability to answer questions with foresight in finding the most appropriate answer in the word boxes so that through these activities, students are expected to focus on listening to the learning delivered by the teacher to be able to answer the questions given by the teacher.

d. The teacher's role as a facilitator and motivator in word square learning

Based on the results of a literature review related to the use of the word square learning model, it was identified that the teacher's role during the learning process was classified as very good because of the teacher's role as a motivator and facilitator. The teacher's role as a motivator and facilitator affects the way students learn, and because of that, students are also helped to achieve their learning goals. Based on student responses with different results shown through the word square learning process, is discussed based on theory, the steps that the teacher has taken towards students lead to the use of Maslow's view because the actions taken can meet the needs of students in achieving maximum learning outcomes. And better than before. If discussed further, according to AH, Maslow explained that human necessities could be classified into five levels of needs known as Maslow's Hierarchy of Needs, starting from basic biological needs to more complex psychological motives, including 1) Physiological needs, namely basic human needs. Such as clothing, food, shelter; 2) The need for security (be it physical security or psychological security including appropriate behavior); 3) Social needs (which are reflected in the five forms of "feeling"); 4) Needs are valued and respected, and 5) The need for self-actualization [28].

Based on the expert's explanation above, it can be seen that Maslow's theory can be applied in various aspects of human life (including in the field of education), one of which is through the way teachers do in meeting the needs of students to achieve maximum learning outcomes. So through this explanation, it can be identified that based on the learning process carried out by previous researchers related to the use of the word square learning model in line with Maslow's theory, because the actions given by the teacher in the learning process, the teacher adjusts to the needs of students, such as consistently paying attention to the social needs of students. And students' self-actualization needs. By paying attention to these needs, the teacher's actions can create a fun learning process that affects student responses that are shown to be positive. It can stimulate the emergence of motivation in students, and students can achieve their learning goals.

Then when viewed from the various actions taken by the teacher based on the learning process carried out by previous researchers related to the use of the word square learning model, it can also be identified that in the learning process carried out, students are driven towards specific goals because of a need. This can be seen from the actions or activities that 
the teacher does when using the word square learning model, more precisely when the teacher distributes activity sheets according to examples to students.

From the activity sheets that are distributed, it will cause an internal drive that makes students try to take any action that leads to the achievement of a goal; students will try to follow the learning process well to answer all questions correctly on the given activity sheet. This is in line with the theory of motivation, according to David McClelland. David McClelland explained that one of the essential things that human needs are; because of encouragement. A person will usually show himself to the desire to influence something if that person has an impulse [28, 29, 23]. In addition, it also explains that another important thing that becomes a human need is the need for achievement (need for achievement). According to him, people who have a great need for achievement usually want to be seen as successful people in life; that person will usually continue to do something better than others.

Based on the explanation above, if studied further, according to data from previous researchers regarding student responses when following the learning process using the word square learning model, it can be stated that it is in line with David McClelland's motivation theory (related to the need for achievement). This can be seen from student responses such as; Students are very enthusiastic about taking part in the learning process, full of enthusiasm, willing to try to complete the practice questions given by the teacher, and have a desire to get good grades.

\section{Conclusion}

Based on the explanation of the research results related to the use of the word square learning model on students' learning motivation, it can be concluded that the use of the word square learning model can stimulate the emergence of inspiration in students, the square learning model is by the characteristics of elementary students, improves students' listening skills, and the teacher's role as facilitator and motivator in learning activities.

\section{Acknowledgments}

The author would like to thank the help or encouragement of supervisors, colleagues, technical staff, and financial support from the university.

\section{Refrences}

[1]. Muhibbin S. Psikologi Belajar. Jakarta: PT Raja Grafindo Persada. (2011).

[2]. Sardiman A. M. Interaksi dan Motivasi Belajar Mengajar. Jakarta: PT Raja Grafindo Persada. (2007).

[3]. Susanti L. Strategi Pembelajaran Berbasis Motivasi. Malang: Elex Media Komputindo. (2020).

[4]. Sunaengsih. Pengelolaan Pendidikan. Sumedang: UPI Sumedang Press. Cucun. (2017).

[5]. Yulianti D, Purnomo E, Pargito P. Pengembangan Media Word Square Berbantu Kartu Uno untuk Meningkatkan Kemampuan Berpikir Kritis. Jurnal Studi Sosial/Journal of Social Studies. 2014;2(4).

[6]. Puthra MW. Penerapan Model Pembelajaran Word Square untuk Meningkatkan Keaktifan dan Hasil Belajar IPA Siswa Kelas V. E-Journal PGSD Universitas Pendidikan Ganesha. 2016;. 4(1). 1-10. 
[7]. Istarani. 58 Model Pembelajaran Inovatif. Medan: Media Persada. (2011).

[8]. Zed M. Metode Penelitian Kepustakaan. Jakarta: Yayasan Obor Indonesia. (2004).

[9]. Faiqoh Z. Analisis Peletakan Genetik Moment Sejarah Matematika dalam Aktivitas Pembelajaran. Skripsi diterbitkan. UIN Sunan Ampel Surabaya. (2013).

[10]. Utami NM, Putra M, Putra DK. MODEL PEMBELAJARAN WORD SQUARE BERBASIS TRI KAYA PARISUDHA BERPENGARUH TERHADAP KOMPETENSI PENGETAHUAN IPS SISWA. Jurnal Pendidikan Multikultural Indonesia. 2020 Jul 24;3(2).

[11]. Mardiana. Penerapan Model Pembelajaran Word Square untuk Meningkatkan Motivasi Belajar Siswa Pada Tema Makanan Sehat di Kelas V B SD Negeri 121/IX Jerambah Bolong Tahun Ajaran 2018/2019. Jurnal Literasiologi, 2019;3(4): 116-123.

[12]. Murwanto E. Peningkatan Motivasi dan Hasil Belajar Materi Lembaga Pemerintahan Desa dan Kecamatan Melalui Penerapan Model Pembelajaran Word Square Pada Siswa Kelas IV SD 2 Getassrabi. Jurnal Prakarsa Paedagogia. 2018;1(2): 152-158.

[13]. Barimbing R. Meningkatkan Motivasi Belajar Siswa dengan Menggunakan Model Pembelajaran Word Square Pada Pelajaran IPA di Kelas V SDN 104204 Sambirejo Timur. Elementary School Journal. 2018;8(2):113-119.

[14]. Wahyuni, Indrawati and Haryana. Penggunaan Model Pembelajaran Word Suare untuk Meningkatkan Motivsi Belajar Siswa Pada Mata Pelajaran IPS Kelas IV SDN 012 Bangko Sempurna Kecamatan Bangko Pusako Kabupaten Rokan Hilir. Jurnal Online Mahasiswa Bidang Keguruan dan Ilmu Pendidikan. 2016; 3(2).

[15]. Marzuki, Gusnardi and Riadi. (). Penggunaan Model Pembelajaran Word Square untuk Meningkatkan Motivasi Belajar Siswa Mata Pelajaran IPS Kelas IV SDN 005 Sedinginan Kecamatan Tanah Putih Kabupaten Rokan Hilir. Jurnal Online Mahasiswa Bidang Keguruan dan Ilmu Pendidikan. 2016;3(2).

[16]. Ginting and Prasetyo. (). Meningkatkan Motivasi Belajar Siswa dengan Menggunakan Model Pembelajaran Word Square pada Pelajaran IPA Kelas IV SD Negeri 050660 Stabat. Jurnal PGSD FIP UNIMED. 2014;2(2): 12-18.

[17]. Lestari Y, Suyanto I, Suryandari KC. Penggunaan Model Pembelajaran Word Square dalam Meningkatkan Motivasi dan Penguasaan Kosakata Bahasa Inggris Siswa Kelas IV SD. Surakarta: Universitas Sebelas Maret. 2013

[18]. Syahrial S, Suarman S, Johan RS. Penggunaan Model Word Square untuk Meningkatkan Motivasi Belajar pada Mata Pelajaran IPS Siswa Kelas V SD Negeri 001 Sedinginan Kecamatan Tanah Putih Kabupaten Rokan Hilir (Doctoral dissertation, Riau University).

[19]. Darmadi H. Pengembangan Model dan Metode Pembelajaran dalam Dinamika Belajar Siswa. Yogyakarta: Deepublish. (2017).

[20]. Pratama TR. Using word square in teaching thematic learning. InProceeding International Seminar of Primary Education 2019 Oct 11;2: 67-71. 
[21]. liyana Ginting E. MENINGKATKAN HASIL BELAJAR SISWA MELALUI MODEL PEMBELAJARAN WORD SQUARE PADA MATA PELAJARAN PENDIDIKAN KEWARGANEGARAAN MATERI ORGANISASI KELAS V SDN 066045 MEDAN HELVETIA TAHUN AJARAN 2018/2019. JURNAL MUTIARA PENDIDIKAN INDONESIA. 2019 Feb 12;4(1):8-14.

[22]. Kurniasari NP, Margunayasa NM. Pengaruh Model Pembelajaran Word Square Berbantuan Media Gambar Terhadap Hasil Belajar IPS Siswa Kelas IV SD Gugus V Kecamatan Tegallalang. MIMBAR PGSD Undiksha. 2013 Jan 8;1(1).

[23]. Marta R. Peningkatan Hasil Belajar IPS dengan Menggunakan Model Word Square Sekolah Dasar. Lembaran Ilmu Kependidikan. 2017 Jul 3;46(1):28-34.

[24]. Nopiyanti NK, Made Sulastri MP, Suwatra II. PENERAPAN MODEL WORD SQUARE BERBANTUAN MIND MAPPING UNTUK MENINGKATKAN AKTIVITAS DAN HASIL BELAJAR IPA SISWA KELAS IV SD. MIMBAR PGSD Undiksha. 2016 Jun 22;4(1).

[25]. Mauritsia A. Meningkatkan Hasil Belajar Siswa Kelas III Melalui Model Pembelajaran Kooperatif Tipe Word Square Di Sd Negeri XXV Wailiti, Sikka Nusa Tenggara Timur. Jurnal Ekonomi, Sosial \& Humaniora. 2020 Jun 15;1(11):126-35.

[26]. Febriani R, Lucyana S. Penerapan Model Pembelajaran Word Square untuk Meningkatkan Hasil Belajar Siswa Kelas X Pada Mata Pelajaran Akuntansi Perusahaan Jasa Di SMK Pasundan 1 Kota Serang. Progress: Jurnal Pendidikan, Akuntansi Dan Keuangan. 2018 Oct 1;1(1):80-94.

[27]. Agiari IG, Sudarma IK, Suarjana IM. Penerapan Model Pembelajaran Word Square Untuk Meningkatkan Keterampilan Menyimak Cerita Pada Siswa Kelas V. Mimbar PGSD Undiksha. 2016 Jul 14;4(1).

[28]. Harisuddin. Secuil Esensi Berpikir Kreatif \& Motivasi Belajar Siswa. Bandung: PT. Panca Terra Firma. (2019).

[29]. Once PB. Improving The Learning Outcomes Of Learning Model Students Word Square Ips Subject Review Of Preparation For Indonesia's Independence In The Class Vocational School Of State 047162 Village Love The Study Year 2018/2019. Proceeding: The Dream Of Millenial Generation To Grow. 2018:85100. 